\title{
KARAKTERISTIK PAPAN PARTIKEL DARI BULU DOMBA, SERBUK GERGAJI DAN SERUTAN KAYU DENGAN PEREKAT UREA FORMALDEHIDA
}

\author{
M. I. Iskandar* dan Achmad Supriadi \\ Pusat Penelitian dan Pengembangan Hasil Hutan \\ Jl. Gunung Batu No. 5, Bogor \\ *e-mail: mi.iskandar53@gmail.com
}

\author{
ABSTRACT \\ Particle Board Characteristics of Fur Sheep, Sawdust and \\ Wood Shavings with Urea Formaldehyde Adhesive
}

\begin{abstract}
Particle board is a board made of particles of wood or other berlignoselulosa bonded with adhesive, then felted heat. Particle board excess, which uses industrial waste materials, uniform size and density, uniform thick and density, the character and quality can be set. This study aims to investigate the characteristics of particle board from sheep's wool, sawdust and wood shavings. The experimental design used was completely randomized design (CRD) with two factors and repeated three times. The first factor combination of pollen fleece $(B)$, with sawdust sengon $(G)$ and wood shavings sengon $(S)$, namely $B_{0} G_{60} S_{40}$ : (0\%: 60\% : 40\%), $B_{10} G_{50} S_{40}:(10 \%: 50 \%: 40 \%), B_{20} G_{40} S_{40}:(20 \%: 40 \%: 40 \%), B_{30} G_{30} S_{40}:(30 \%: 30 \%$ : $40 \%$ and the second factor consists of the physical properties (density, moisture content, thickness swelling and water absorption) and character of mechanical factor (flexural strength, modulus of elasticity, perpendicular and surface strength and straight screw holding). The results of the research were to produce a density value was between 0.69 to $0.78 \mathrm{~g} / \mathrm{cm}^{3}$, water content with an average of $6.49 \%$, a value between 32.36 to $83.9 \%$ thickness swelling, water absorption between $89,04-169.15 \%$, the flexural strength values between 68.4 to $121.8 \mathrm{kgf} / \mathrm{cm}^{2}$, elastic modulus was between 671.84 to $1381.51 \mathrm{kgf} / \mathrm{cm}^{2}$, the value of tensile strength perpendicular of the surface was between 0.44 to $1.3 \mathrm{kgf} / \mathrm{cm}^{2}$ and screw holding strength value was between 6.0 to $22.3 \mathrm{~kg}$. the higher use of powder fleece might degrade the quality of particle board, otherwise use the higher adhesive could improve the quality of particle board. The study of particle board and fleece, saws and wood shavings was on average below of the national Indonesia standard, except for the density and moisture content, for flexural strength was only partially standard value.
\end{abstract}

Key words: fleece, characteristics, particle board, sawdust, wood shavings.

\begin{abstract}
ABSTRAK
Papan partikel merupakan suatu papan yang terbuat dari partikel-partikel kayu atau bahan berlignoselulosa lainnya yang diikat dengan perekat, kemudian dikempa panas. Kelebihan papan partikel, yaitu menggunakan bahan limbah industri, ukuran dan kerapatan seragam, tebal dan kerapatan seragam, sifat dan kualitasnya dapat diatur. Penelitian ini bertujuan untuk mengetahui karakteristik papan partikel dari bulu domba, serbuk gergaji dan serutan kayu. Rancangan percobaan yang digunakan adalah Rancangan Acak Lengkap (RAL) pola faktorial dengan dua faktor dan ulangan sebanyak tiga kali. Faktor pertama kombinasi serbuk bulu domba (B), dengan serbuk gergaji kayu sengon (G) dan serutan kayu sengon (S), yaitu $\mathrm{B}_{0} \mathrm{G}_{60} \mathrm{~S}_{40}$ : (0\%: $60 \%: 40 \%), \mathrm{B}_{10} \mathrm{G}_{50} \mathrm{~S}_{40}:(10 \%: 50 \%: 40 \%), \mathrm{B}_{20} \mathrm{G}_{40} \mathrm{~S}_{40}:(20 \%: 40 \%: 40 \%), \mathrm{B}_{30} \mathrm{G}_{30} \mathrm{~S}_{40}:(30 \%: 30 \%$ : $40 \%$ ) dan faktor kedua terdiri dari sifat fisis (kerapatan, kadar air, pengembangan tebal dan daya serap air) dan sifat mekanis (kuat lentur, modulus elastisitas, kuat tarik tegal lurus permukaan dan kuat pegang sekrup). Hasil penelitian menghasilkan nilai kerapatan antara $0,69-0,78 \mathrm{~g} / \mathrm{cm}^{3}$, nilai kadar air dengan rata-rata $6,49 \%$, nilai pengembangan tebal antara 32,36-83,9\%, daya serap air antara $89,04-169,15 \%$, nilai kuat lentur antara $68,4-121,8 \mathrm{kgf} / \mathrm{cm}^{2}$, nilai modulus elastisitas antara $671,84-1381,51 \mathrm{kgf} / \mathrm{cm}^{2}$, nilai kuat tarik tegak lurus permukaan antara $0,44-1,3 \mathrm{kgf} / \mathrm{cm}^{2}$ dan nilai kuat pegang sekrup antara $6,0-22,3 \mathrm{~kg}$. penggunakan serbuk bulu domba yang semakin tinggi dapat menurunkan kualitas papan partikel, sebaliknya penggunaan perekat yang semakin tinggi dapat meningkatkan kualitas papan partikel. Penelitian papan partikel dan bulu domba, gergaji dan serutan kayu rata-rata di bawah standar nasional Indonesia, kecuali untuk kerapatan dan kadar air, untuk kuat lentur hanya sebagian yang masuk standar.
\end{abstract}

Kata kunci : bulu domba, karakteristik, papan partikel, serbuk gergaji, serutan kayu. 


\section{PENDAHULUAN}

Bulu domba atau wol merupakan penutup alami tubuh domba yang berfungsi mempertahankan tubuh dari pengaruh panas dan udara dingin sehingga cocok untuk ke-perluan bahan sandang manusia. Pengguna-an serat wol sebagai bahan sandang di Indonesia sangat kecil karena domba lokal Indonesia masih menghasilkan wol yang sangat kasar. Pengadaan wol untuk sandang memerlukan kondisi cuaca dan jenis domba yang khusus. Saat ini kondisi peternakan domba di Indonesia bukan ditujukan sebagai penghasil serat wol, tetapi untuk produksi daging dan kulit saja, oleh karena itu perlu adanya penelitian untuk menghasilkan produk baru berbahan bulu domba yang bermanfaat dan mempunyai nilai ekonomis tinggi.

Bulu domba dilihat dari segi fisik merupaka serat alami yang disusun oleh protein yang disebut keratin yang kokoh dan tahan terhadap lingkungan karena memiliki ikatan silang sulfur yang merubah bagian lunak protein menjadi struktur bulu yang kuat (Leeder, 1984). Laju pertumbuhan bulu domba dipengaruhi oleh jenis domba, iklim dan kualitas pakan yang diberikan.

Sebagai upaya pemanfaatan bulu domba adalah dengan memanfaatkannya sebagai bahan baku papan partikel. Pembuatan papan partikel ini memperhatikan sifat bulu domba sebagai insulator yang baik, dapat dikempa dan kuat. Papan partikel adalah salah satu produk panel kayu yang terbuat dari partikel-partikel kayu atau bahan yang berlignoselulosa lainnya yang diikat dengan perekat, kemudian dikempa panas (Maloney, 1993).

Tujuan dari penelitian ini adalah untuk mengetahui karakteristik papan partikel yang berbahan baku bulu domba yang diserbukkan, serbuk gergaji dan serutan kayu sengon (Paraserianthes falcataria) dengan perekat urea formaldehida yang dibuat dengan metode tiga lapis.

\section{BAHAN DAN METODE}

\section{Bahan}

Bahan yang digunakan dalam penelitian ini adalah bulu domba, serbuk gergaji kayu sengon, serutan kayu sengon dan perekat urea formaldehida.

\section{Metode}

Penelitian dilakukan dengan mengguna-kan rancangan acak lengkap pola faktorial dengan dua faktor perlakuan, yaitu faktor pertama komposisi serbuk bulu domba, ser-buk gergaji dan serutan kayu sengon. Faktor kedua persentase perekat yang digunakan. Banyaknya ulangan pada masing-masing perlakuan adalah tiga kali. Metode pe-nelitian berdasarkan Steel dan Torrie (2014) adalah sebagai berikut:

\section{a. Persiapan Partikel}

Bulu domba yang diperoleh terlebih dahulu melalui beberapa proses, diantaranya: pencukuran, perendaman dan pencucian dengan air bersih, pencucian dan peren-daman dengan deterjen sebanyak 1\% (10 g/l) selama 24 jam, pembilasan sisa deterjen dengan air bersih dan penjemuran selama 1-2 hari di bawah sinar matahari. Bulu domba tersebut kemudian diserbukkan dengan menggunakan Willey mill dengan lubang saringan berukuran $2 \mathrm{~mm}$. Serbuk gergaji juga disaring dengan ukuran $2 \mathrm{~mm}$. Kemu-dian serbuk bulu domba, serbuk gergaji dan serutan kayu sengon masingmasing dimasukkan ke dalam oven pada suhu $60^{\circ} \mathrm{C}$ selama 24 jam. Setelah itu kemudian dioven pada suhu $105^{\circ} \mathrm{C}$ untuk menghasilkan bahan partikel dengan berat kering mutlak.

\section{b. Persiapan Perekat}

Bahan perekat yang digunakan adalah urea formaldehida. Tingkat perekat yang diperlukan untuk pembuatan papan partikel dengan ukuran $30 \mathrm{~cm} \times 30 \mathrm{~cm} \times 1 \mathrm{~cm}$ adalah $16 \%, 18 \%$ dan $20 \%$ dari berat kering mutlak partikel. 


\section{c. Pembuatan Papan Partikel}

Tahap berikutnya setelah persiapan partikel dan perekat ialah pencampuran par-tikel dengan perekat secara manual dengan menggunakan ember. Perekat dicampurkan ke permukaan partikel secara manual dengan menuangkan perekat ke dalam ember yang berisikan partikel-partikel, kemudian diaduk sampai rata dengan menggunakan kedua tangan sampai partikel dan perekat tercampur merata. Pembuatan papan partikel dilakukan dengan cara pembuatan tiga lapis, yaitu kedua sisi lapis terluar dibuat dengan menggunakan serat kayu sengon dengan cara membagi dua dari jumlah serutan kayu yang digunakan dan lapisan tengah dibuat dengan campuran bulu domba dengan serbuk gergaji kayu sengon. Setelah perlakuan perekatan, adonan dibentuk dengan cetakan datar yang berukuran 30 $\mathrm{cm} \times 30 \mathrm{~cm} \times 1 \mathrm{~cm}$ dikempa panas dengan panas suhu $130^{\circ} \mathrm{C}$ dan tekanan spesifik kempa sebesar $30 \mathrm{~kg} / \mathrm{cm}^{2}$ selama 10 menit (Purnawulan 2004).

\section{d. Pembuatan Contoh Uji dan Pengujian \\ Pembuatan contoh uji mengacu pada SNI 03-2105-1996.}

\section{HASIL DAN PEMBAHASAN}

\section{Kerapatan}

Nilai rataan kerapatan papan partikel dari serbuk bulu domba, serbuk gergaji dan serutan kayu sengon dengan menggunakan perekat urea formaldehida terdapat pada Tabel 1. Nilai rataan kerapatan papan partikel berkisar antara 0,69-0,78 $\mathrm{g} / \mathrm{cm}^{3}$, nilai kerapatan ini hampir sesuai dengan target yang diinginkan yaitu sebesar $0,70 \mathrm{~g} / \mathrm{cm}^{3}$. Nilai tersebut termasuk ke dalam golongan papan partikel berkerapatan sedang (Medium density particleboard), yaitu papan partikel yang mempunyai kerapatan antara 0,4-0,8 g/ $\mathrm{cm}^{3}$ (Maloney, 1993). Kerapatan yang dihasilkan pada penelitian ini masih di bawah nilai yang dihasilkan oleh penelitian Nafitiara (2004), yaitu sekitar $0,96 \mathrm{~g} / \mathrm{cm}^{3}$ sampai dengan $0,84 \mathrm{~g} / \mathrm{cm}^{3}$. Nilai tersebut termasuk kategori papan partikel berkerapatan tinggi.

Pengaruh konsentrasi perekat yang digunakan pada uji Polinomial Ortogonal membentuk kurva linier dengan persamaan $\mathrm{Y}=0,55+0,01 \mathrm{X}$ dengan $\mathrm{R}^{2}=$ $100 \%$. Grafik ini menunjukkan bahwa semakin banyaknya perekat yang digunakan semakin tinggi nilai kerapatan yang dihasilkan (Tsoumis, 2001).

\section{Kadar Air}

Nilai rataan kadar air papan partikel dapat dilihat pada Tabel 2. Nilai kadar air penelitian ini lebih baik dibandingkan penelitian Nafitiara (2004) yang menghasilkan nilai kadar air sekitar 5,4\% sampai dengan $20,36 \%$.

Tabel 1. Nilai Rataan Kerapatan Papan Partikel dari Serbuk Bulu Domba, Serbuk Gergaji dan Serutan Kayu Sengon $\left(\mathrm{g} / \mathrm{cm}^{3}\right)$

\begin{tabular}{ccccc}
\hline \multirow{2}{*}{$\begin{array}{c}\text { Serbuk Bulu Domba } \\
(\%)\end{array}$} & 16 & 18 & Rerekat $(\%)$ & \\
\cline { 2 - 4 } & 0,69 & 0,73 & 0.72 & 0,71 \\
10 & 0,71 & 0,74 & 0,78 & 0,74 \\
20 & 0,74 & 0,74 & 0,72 & 0,73 \\
30 & 0,71 & 0,71 & 0,78 & 0,73 \\
\hline Rataan & 0,71 & 0,73 & 0,75 & \\
\hline SNI 03-2105 (1996) & \multicolumn{2}{c}{$0,5-0,9$} \\
\hline
\end{tabular}


Tabel 2. Nilai Rataan Kadar Air Papan Partikel dari Serbuk Bulu Domba, Serbuk Gergaji dan Serutan Kayu Sengon (\%)

\begin{tabular}{|c|c|c|c|c|}
\hline \multirow{2}{*}{$\begin{array}{c}\text { Serbuk Bulu Domba } \\
(\%)\end{array}$} & \multicolumn{3}{|c|}{ Perekat (\%) } & \multirow[t]{2}{*}{ Rataan } \\
\hline & 16 & 18 & 20 & \\
\hline 0 & 6,59 & 6,71 & 6,21 & 6,50 \\
\hline 10 & 6,76 & 6,25 & 6,06 & 6,36 \\
\hline 20 & 6,84 & 6,01 & 6,59 & 6,48 \\
\hline 30 & 6,68 & 6,99 & 6,15 & 6,61 \\
\hline Rataan & 6,72 & 6,49 & 6,25 & 6,49 \\
\hline SNI 03-2105 (1996) & \multicolumn{4}{|c|}{ Maks 14} \\
\hline
\end{tabular}

Berdasarkan analisa ragam, nilai kadar air tidak dipengaruhi secara nyata oleh banyaknya serbuk bulu domba, jumlah perekat dan interaksi kedua faktor tersebut. Nilai kadar air yang tidak nyata dipengaruhi oleh serbuk bulu dan perekat mungkin disebabkan nilai kadar air lebih dipengaruhi oleh suhu kempa dan kerapatan papan partikel. Suhu kempa yang tinggi membuat partikel kayu mengering dan pada saat air dikeluarkan dari dinding-dinding sel, molekulmolekul berantai panjang bergerak saling mendekat dan ikatan antar partikel menjadi kuat sehingga pori-pori menjadi lebih kecil (Haygreen dan Bowyer,1996).

\section{Pengembangan Tebal}

Pengembangan tebal merupakan besar-nya presentase pengembangan tebal papan partikel setelah direndam air selama 24 jam (Nafitiara 2004). Pengembangan tebal pada penelitian ini berkisar antara 32,36-83,90\% yang disajikan pada Tabel 3.

Hasil yang di bawah standar diduga karena selain penggunaan partikel kayu dan bulu domba yang bersifat higroskopis, juga karena ukuran partikel yang kecil membuat luas penampang masuknya air menjadi lebih besar dan standar yang digunakan masih untuk papan partikel yang terbuat dari kayu, sedangkan penelitian ini bahan papan partikel kayu dicampur dengan bulu domba. Nilai pengembangan tebal yang dihasilkan pada penelitian ini lebih tinggi dibandingkan hasil yang diperoleh Nafiitiara (2004).

Berdasarkan sidik ragam nilai pengem-bangan tebal sangat nyata dipengaruhi oleh serbuk bulu domba dan jumlah perekat $(\mathrm{P}<0,01)$, sedangkan interaksi kedua faktor secara nyata juga mempengaruhi nilai pengembangan tebal $(\mathrm{P}<0,05)$.

\section{Daya Serap Air}

Nilai daya serap air pada penelitian ini berkisar antara 89,04-169,15\%, nilai ini lebih tinggi dibandingkan nilai yang di-dapatkan pada penelitian Nafiitiara (2004), yaitu berkisar antara 55,83$125,33 \%$. Hal ini diduga penggunaan partikel bulu domba yang diserbukkan dapat mempertinggi luas penampang masuknya air, serta penggunaan perekat yang lebih rendah dari pada penelitian Nafitiara (2004), yang meng-gunakan kadar perekat sebesar $25 \%$.

Tabel 3. Nilai Rataan Pengembangan Tebal Papan Partikel dari Serbuk Bulu Domba, Serbuk Gergaji dan Serutan Kayu Sengon (\%)

\begin{tabular}{ccccc}
\hline \multirow{2}{*}{$\begin{array}{c}\text { Serbuk Bulu Domba } \\
(\%)\end{array}$} & 16 & 18 & Rataan \\
\cline { 2 - 4 } & 44,84 & 42,60 & 32,36 & 39,93 \\
10 & 46,39 & 39,17 & 38,28 & 41,28 \\
20 & 67,21 & 60,83 & 39,28 & 55,77 \\
30 & 83,90 & 82,67 & 61,62 & 76,06 \\
\hline Rataan & 60,59 & 56,32 & 42,89 & \\
\hline SNI 03-2105 (1996) & \multicolumn{3}{c}{ Maks 12 } \\
\hline
\end{tabular}


Tabel 4. Nilai Rataan Daya Serap Air Papan Partikel dari Serbuk Bulu Domba, Serbuk Gergaji dan Serutan Kayu Sengon (\%)

\begin{tabular}{ccccc}
\hline Serbuk Bulu & \multicolumn{3}{c}{ Perekat $(\%)$} & Rataan \\
\cline { 2 - 4 } Domba $(\%)$ & 16 & 18 & 20 & \\
\hline 0 & 117,83 & 110,83 & 91,83 & 106,83 \\
10 & 124,61 & 102,72 & 89,04 & 104,46 \\
20 & 145,70 & 142,16 & 100,16 & 129,34 \\
30 & 169,15 & 158,01 & 124,56 & 150,57 \\
\hline Rataan & 139,32 & 128,43 & 101,40 & \\
\hline
\end{tabular}

Tabel 5. Nilai Rataan Kuat Lentur Papan Partikel dari Serbuk Bulu Domba, Serbuk Gergaji dan Serutan Kayu Sengon $\left(\mathrm{kgf} / \mathrm{cm}^{2}\right)$

\begin{tabular}{ccccc}
\hline Serbuk Bulu & \multicolumn{3}{c}{ Perekat $(\%)$} & Rataan \\
\cline { 2 - 4 } Domba $(\%)$ & 16 & 18 & 20 & \\
\hline 0 & 112,2 & 98,4 & 112,2 & 107,60 \\
10 & 103,8 & 98,4 & 120,0 & 107,40 \\
20 & 69,0 & 121,8 & 89,1 & 93,30 \\
30 & 68,4 & 87,6 & 93,0 & 83,00 \\
\hline Rataan & 88,35 & 101,55 & 103,58 & \\
\hline SNI 03-2105 (1996) & \multicolumn{3}{c}{ Min 80} \\
\hline
\end{tabular}

Tabel 6. Nilai Rataan Modulus Elastisitas Papan Partikel dari Serbuk Bulu Domba, Serbuk Gergaji dan Serutan Kayu Sengon $\left(\mathrm{kgf} / \mathrm{cm}^{2}\right)$

\begin{tabular}{ccccc}
\hline Serbuk Bulu & \multicolumn{3}{c}{ Perekat $(\%)$} & Rataan \\
\cline { 2 - 4 } Domba $(\%)$ & 16 & 18 & 20 & \\
\hline 0 & 844,95 & 1381,51 & 918,42 & 1048,30 \\
10 & 818,90 & 827,13 & 881,74 & 842,59 \\
20 & 966,37 & 773,65 & 671,84 & 803,95 \\
30 & 678,92 & 702,84 & 613,93 & 665,23 \\
\hline Rataan & 827,29 & 921,28 & 771,48 \\
\hline SNI 03-2105 (1996) & \multicolumn{4}{c}{ Min 15000 } \\
\hline
\end{tabular}

Nilai daya serap air sangat nyata dipengaruhi oleh serbuk bulu domba $(\mathrm{P}<0,01)$ dan jumlah perekat yang digunakan $(\mathrm{P}<0,01) \quad$ tetapi tidak dipengaruhi secara nyata oleh interaksi kedua faktor tersebut. Pengaruh jumlah serbuk bulu domba yang digunakan pada uji lanjut Polinomial Ortogonal membentuk kurva kuadratik dengan persamaan $\mathrm{Y}=105,434-0,144 \mathrm{X}+$ $0,057 X^{2}$ dengan $R^{2}=97,2 \%$.

\section{Kuat Lentur}

Nilai rataan kuat lentur penelitian disajikan pada Tabel 5. Nilai kuat lentur pada Tabel 5 berkisar antara 68,4-121,8 $\mathrm{kgf} / \mathrm{cm}^{2}$ sebagian besar dari nilai kuat lentur pada penelitian ini sudah memenuhi SNI 03-2105 (1996), yaitu minimal $80 \mathrm{kgf} / \mathrm{cm}^{2}$, kecuali pada kombinasi serbuk bulu domba $20 \%$ dan $30 \%$ dengan perekat $16 \%$. Hal ini diduga karena bulu domba yang bersifat lunak sehingga mudah patah, selain itu standar yang digunakan masih untuk papan partikel yang terbuat dari kayu. Nilai yang dihasilkan pada penelitian ini tidak jauh berbeda dari penelitian Nafiitiara (2004), yaitu sebesar 76,24-127,85 $\mathrm{kgf} / \mathrm{cm}^{2}$. 
Hasil sidik ragam untuk nilai kuat lentur secara nyata dipengaruhi oleh serbuk bulu domba $(\mathrm{P}<0,05)$ tetapi tidak dipengaruhi secara nyata oleh perekat dan interaksi kedua faktor tersebut. Pengaruh penggunaan serbuk bulu domba membentuk kurva liniear dengan persamaan $\mathrm{Y}=111,01-0,879 \mathrm{X}$ dengan $\mathrm{R}^{2}=90 \%$.

\section{Modulus Elastisitas}

Nilai modulus elastisitas dapat dilihat pada Tabel 6. Nilai modulus elastisitas (MOE) pada penelitian ini sedikit lebih rendah dibandingkan dengan nilai yang didapatkan oleh Nafitiara (2004), yaitu $760 \mathrm{kgf} / \mathrm{cm}^{2}-1560 \mathrm{kgf} / \mathrm{cm}^{2}$.

Menurut hasil sidik ragam nilai modulus elastisitas sangat nyata dipengaruhi oleh serbuk bulu domba $(\mathrm{P}<0,01)$ tetapi tidak dipengaruhi oleh kadar perekat dan interaksi kedua faktor tersebut. Penggunaan uji lanjut Polinomial Ortogonal menjelaskan bahwa pengaruh penggunaan serbuk bulu domba menghasilkan kurva linier dengan persamaan $\mathrm{Y}=1018,20-11,88 \mathrm{X}$ dengan $\mathrm{R}^{2}=93,8 \%$.

\section{Kuat Tarik Tegak Lurus Permukaan}

Nilai uji kuat tarik tegak lurus permukaan untuk semua kombinasi perlakuan disajikan pada Tabel 7 , namun masih di bawah standar SNI 03-2105 (1996), yaitu minimal $1,5 \mathrm{kgf} / \mathrm{cm}^{2}$. Nilai yang di bawah standar tersebut diduga karena pencampuran perekat yang kurang baik yang disebabkan ukuran partikel kecil sehingga luas penampang yang harus dibasahi oleh perekat semakin tinggi maka perlu proses pencampuran yang sempurna. Jenis perekat yang digunakan juga diduga masih kurang cocok digunakan untuk partikel dari bulu domba. Nilai yang dihasilkan pada penelitian ini masih di bawah hasil yang didapatkan oleh Nafitiara (2004).

Nilai kuat tarik tegak lurus permukaan menurut hasil sidik ragam ternyata dipengaruhi sangat nyata oleh penggunaan serbuk bulu domba $(\mathrm{P}<0,01)$ dan secara nyata dipengaruhi interaksi antara serbuk bulu domba dan perekat $(\mathrm{P}<0,05)$. Uji Polinomial Ortogonal untuk interaksi kedua faktor menghasilkan kurva kubik dengan persamaan $\mathrm{Y}_{\mathrm{UF} 16 \%}=0,0001 \mathrm{x}^{2}-0,0048 \mathrm{x}$ $+1,05$ dengan $\mathrm{R}^{2}=100 \%, \mathrm{Y}_{\mathrm{UF} 18 \%}=$ $0,0001 x^{3}-0,0063 x^{2}+0,0691 x+0,593$ dengan $\mathrm{R}^{2}=100 \%$ dan $\mathrm{Y}_{\mathrm{UF} 20 \%}=$ $0,0014 x^{2}-0,0638 x+1,3092$ dengan $R 2$ $=99,5 \%$.

\section{Kuat Pegang Sekrup}

Nilai rataan kuat pegang sekrup dapat dilihat pada Tabel 8. Nilai kuat pegang sekrup setelah dianalisa sidik ragam sangat nyata dipengaruhi oleh serbuk bulu domba, perekat dan interaksi kedua faktor tersebut $(\mathrm{P}<0,01)$. Uji Polinomial Ortogonal untuk interaksi serbuk bulu domba dan perekat menghasilkan kurva kubik dengan persamaan $\mathrm{Y}_{\mathrm{UF} 16 \%}=0,0006 \mathrm{x}^{3}-0,0327 \mathrm{x}^{2}$ $+0,03022 x+9,0667$ dengan $R^{2}=100 \%$, $\mathrm{Y}_{\mathrm{UF} 18 \%}=0,0002 \mathrm{x}^{3}-0,1007 \mathrm{x}^{2}+1,0889 \mathrm{x}$ $+10,533$ dengan $\mathrm{R}^{2}=100 \%$ dan $\mathrm{Y}_{\mathrm{UF} 20 \%}$ $=0,0048 \mathrm{x}^{3}-0,2467 \mathrm{x}^{2}+2,8278 \mathrm{x}+$ 14,533 dengan $\mathrm{R}^{2}=100 \%$.

Tabel 7. Nilai Rataan Kuat Tarik Tegak Lurus Permukaan Papan Partikel dari Serbuk Bulu Domba, Serbuk Gergaji dan Serutan Kayu Sengon (\%)

\begin{tabular}{ccccc}
\hline $\begin{array}{c}\text { Serbuk Bulu Domba } \\
(\%)\end{array}$ & \multicolumn{3}{c}{ Perekat (\%) } & Rataan \\
\cline { 2 - 4 } 0 & 1,05 & 0,59 & 18 & \\
\hline 0 & 0,84 & 0,79 & 0,84 & 0,98 \\
20 & 0,44 & 0,54 & 0,56 & 0,82 \\
30 & 0,62 & 0,67 & 0,64 & 0,51 \\
Rataan & 0,74 & 0,65 & 0,83 & 0,65 \\
\hline SNI 03-2105 (1996) & \multicolumn{3}{c}{ Min 1,5} \\
\hline
\end{tabular}


Tabel 8. Nilai Rataan Kuat Pegang Sekrup Papan Partikel dari Serbuk Bulu Domba, Serbuk Gergaji dan Serutan Kayu Sengon (\%)

\begin{tabular}{ccccc}
\hline Serbuk Bulu Domba & \multicolumn{3}{c}{ Perekat $(\%)$} & Rataan \\
\cline { 2 - 4 }$(\%)$ & 16 & 18 & 20 & \\
\hline 0 & 9,06 & 10,53 & 14,53 & 11,38 \\
10 & 9,47 & 13,3 & 22,93 & 15,24 \\
20 & 7,20 & 7,87 & 10,73 & 8,60 \\
30 & 6,13 & 6,00 & 6,67 & 6,27 \\
\hline Rataan & 7,97 & 9,43 & 13,72 & \\
\hline SNI 03-2105 (1996) & \multicolumn{2}{c}{$30-50$} \\
\hline
\end{tabular}

\section{KESIMPULAN}

Penelitian papan partikel yang terbuat dari serbuk bulu domba, serbuk gergaji dan serutan kayu sengon mempunyai nilai kerapatan antara 0,69 $0,78 \mathrm{~g} / \mathrm{cm}^{3}$, nilai kadar air dengan ratarata $6,49 \%$, nilai pengembangan tebal antara $32,36-83,9 \%$, daya serap air antara 89,04-169,15\%, nilai kuat lentur antara $68,4-121,8 \mathrm{kgf} / \mathrm{cm}^{2}$, nilai modulus elastisitas antara 671,84-1381,51 $\mathrm{kgf} / \mathrm{cm}^{2}$, nilai kuat tarik tegak lurus permukaan antara $0,44-1,3 \mathrm{kgf} / \mathrm{cm}^{2}$ dan nilai kuat pegang sekrup $6-22,3 \mathrm{~kg}$.

Berdasarkan hasil penelitian yang telah dilakukan dapat disimpulkan bahwa semakin besar penggunaan serbuk bulu domba dapat mengurangi sifat fisis dan mekanis papan partikel, sebaliknya penggunaan perekat yang semakin besar dapat memperbaiki sifat fisis mekanis papan partikel. Pembuatan papan partikel dari campuran serbuk bulu domba, serbuk gergaji dan serutan kayu sengon masih di bawah standar SNI 03-2105 (1996), kecuali untuk kadar air dan kerapatan, untuk kuat lentur hanya sebagian yang masuk standar. Penggunaan bulu domba yang diserbukkan dan pembuatan papan partikel dengan metode tiga lapis dapat memperbaiki tekstur dan penampakan papan partikel.

\section{DAFTAR PUSTAKA}

Dewan Standarisasi Nasional. 1996. Mutu Papan Partikel. (SNI No. 03-2105). Jakarta.

Haygreen J.G, Bowyer. 1996. Hasil Hutan dan Ilmu Kayu. Suatu Pengantar. Hardikusumo SA. Penerjemah: Prawirohatmodjo S, Editor. Yogyakarta: Gadjah Mada University Press. Terjemahan dari Forest Product and Wood Science. An Introduction.

Leeder J. B. 1984. Wool Natur's Wonder Fibre. Australian Textiles Publishers. Belinont, Australia.

Maloney T. M. 1993. Modern Particleboard and Dry Process Fiberboard Manufacturing. Miller Freeman Publication, San Francisco.

Nafitiara S. 2004. Sifat fisik dan mekanik papan partikel bulu domba. Skripsi. Fakultas Peternakan, Institut Pertanian Bogor, Bogor.

Purnawulan E. 2004. Sifat fisis-mekanis papan partikel dari bulu domba dan serbuk gergaji pada kombinasi suhu dan tekanan kempa yang berbeda. Skripsi. Jurusan Ilmu Produksi Ternak, Fakultas Peternakan, Institut Pertanian Bogor, Bogor. 
16 Karakteristik papan partikel dari bulu domba, serbuk gergaji dan serutan kayu.....

Steel R. G. dan J. H. Torrie. 2014. Prinsip dan Prosedur Statistika Suatu Pendekatan Biometrik. Terjemahan: B. Sumantri. Cetakan ke-3 PT. Gramedia Pustaka Utama, Jakarta.

Tsoumis G. 2001. Science and Technology of Wood. Van Nostrand Reinhold.New York. 